\title{
Differential impact of top-down and bottom-up forces in structuring freshwater bacterial communities
}

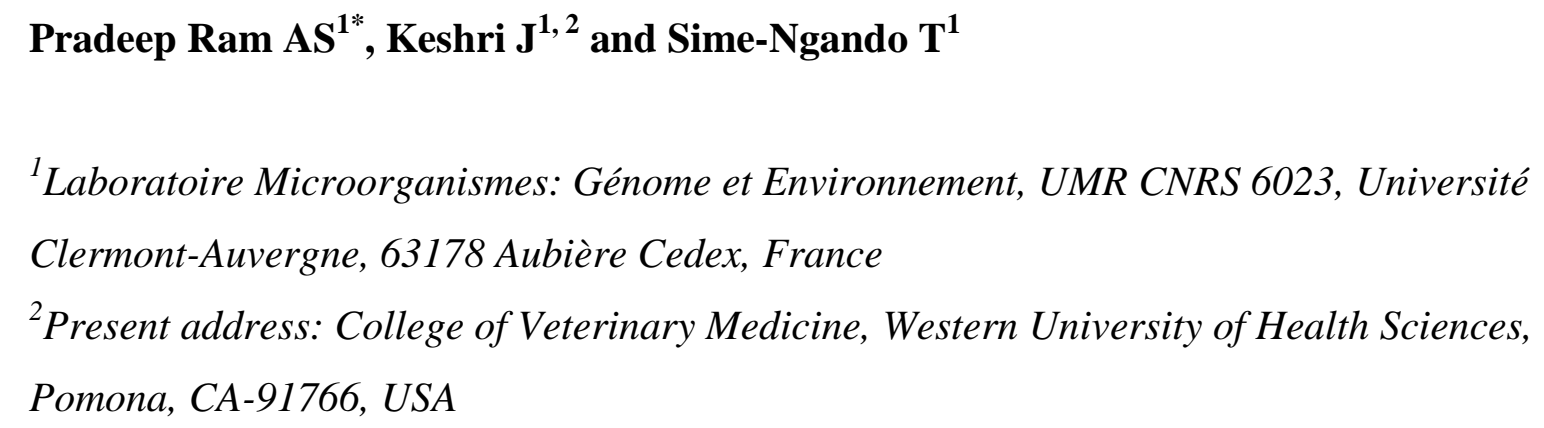
(16

Running title: Bottom-up and top-down effects on bacterial community

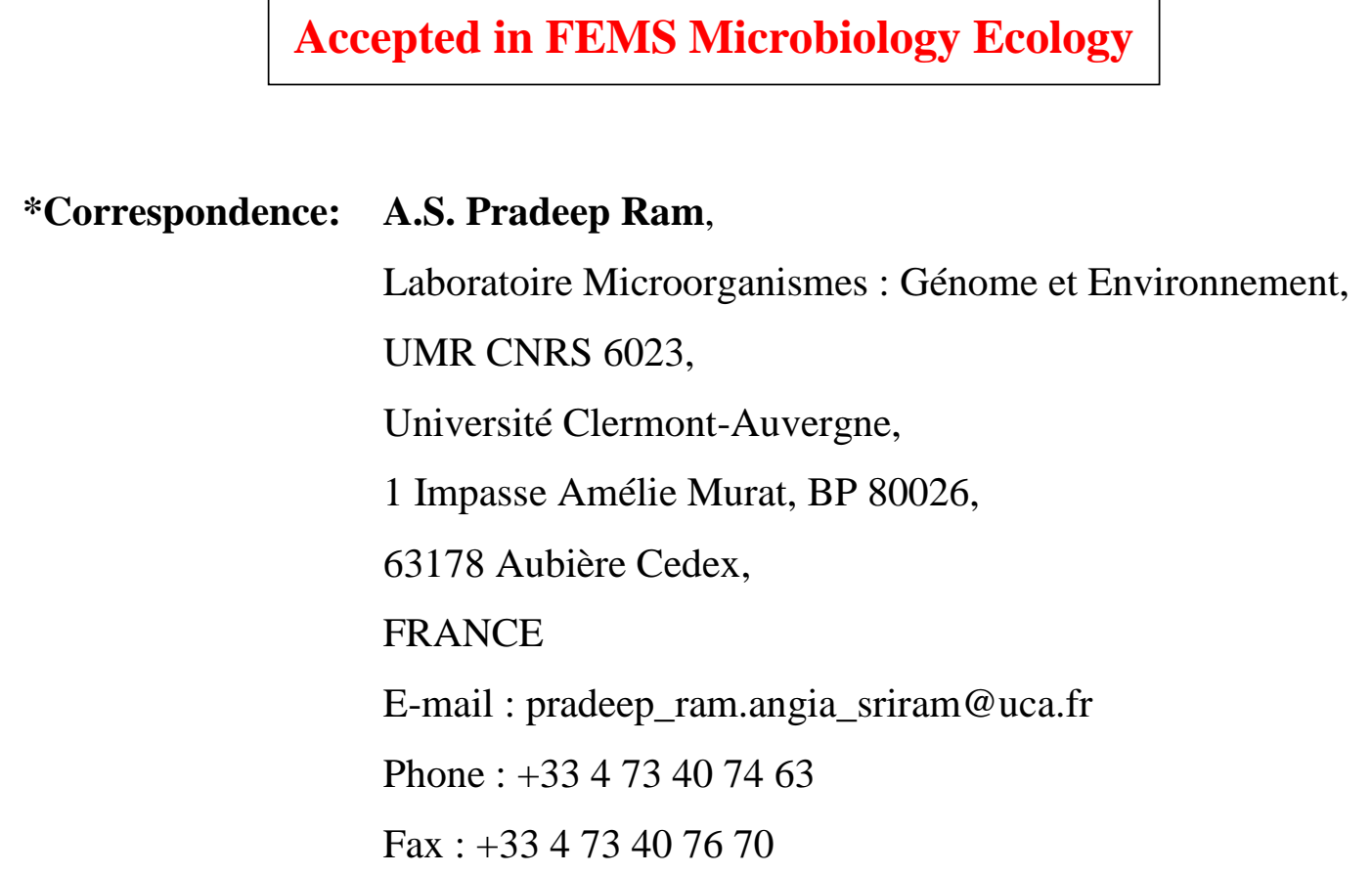




\section{ABSTRACT}

Limited data exists on the simultaneous impact of bottom-up (nutrients) and top-down (viruses and heterotrophic nanoflagellates) forces in shaping freshwater bacterial communities. In our laboratory microcosms, nutrient additions (organic and inorganic) and viral reduction approach led to the proliferation of high nucleic acid (HNA) bacterial subpopulation without an increase in phage abundance. High viral-mediated bacterial lysis in the presence of nanoflagellates yielded high proportion of low nucleic acid bacterial subpopulation. 16S rRNA gene sequence analysis indicated that members of class Proteobacteria and Bacteroidetes evoked differential responses to nutrients and mortality forces thereby resulting in differences $(\mathrm{p}<0.001)$ in bacterial community composition and diversity, as observed from ANOSIM and UniFrac analysis. Bacterial species richness (Chao) and diversity (Shannon) index was significantly higher $(\mathrm{p}<0.001)$ in the presence of both the top-down factors and viruses alone, whereas lower host diversity was observed under nutrient relaxation of growth limiting substrates due to the explosive growth of opportunistic HNA bacterial subpopulation. Our results are in agreement with the theoretical model of 'Killing the Winner' where the availability of growth limiting substrates can act as a stimulating factor for host community composition while top-down forces can operate in the control of host diversity.

Keywords: bacteria, viruses, nutrients, bacterial community, 16S rRNA gene sequencing, freshwater microcosms 


\section{INTRODUCTION}

Top-down control of bacterial populations especially by viruses has received attention in recent years since the finding of its high numbers in a wide variety of aquatic systems (Weitz and Wilhelm 2012; Sime-Ngando 2014). Together with bacterivorous nanoflagellates, viruses are now considered to be a major ecological determinant in regulating the structure and function of heterotrophic microbial communities (Suttle 2007; Sandaa et al. 2009). The recognition of viruses as dynamic components of planktonic communities through their destruction up to $60 \%$ of daily produced bacterial biomass in freshwater systems has challenged the conventional view that bacterial communities were largely thought to be impacted by bottom up factors. Among the interacting forces structuring bacterial communities, most attention has been on bottom-up effects (physical and chemical parameters), with lesser focus given to bacterial interaction with other segments of a microbial community such as viral or protistan activity (Bouvy et al. 2011; Pradeep Ram et al. 2016).

Within the microbial part of aquatic systems, bottom-up (nutrient supply) and topdown (protistan grazing and viral lysis) processes are known to influence and control bacterial community composition and diversity in time and space. Viruses and protists can directly impact bacterial communities either through their host specific lysis and size selective grazing respectively or indirectly through the alteration of organic pools by mortality processes (Liu et al. 2015). Previous studies carried out in freshwater systems have revealed that under nutrient limiting conditions, synergistic interactions between grazing and viral lysis tend to generate growth resources for fueling bacterial activity (Simek et al. 2001; Pradeep Ram and SimeNgando 2008), however their net influence on the taxonomical resolution of bacterial communities is less clearly understood. Detail examination of how the trophic interactions such as the supply of resources and mortality factors that lead to alteration of bacterial community composition and their diversity have been less studied. In seawater microcosms, relatively few moderate changes in bacterial community amidst of high viral abundance and their apparent high turnover made it difficult to distinguish statistically significant effects of viruses on bacterial community composition (Schwalbach et al. 2004). In perialpine lakes, multivariate ordination analyses suggested that bottom-up factors (nutrients and temperature) was the driving force behind the bacterial community shifts in spite of prevailing high viral abundances (Berdjeb et al. 2011). Considering the complexity and the importance of interactions between bottom-up and top-down factors, we used a reconstitution approach 
using incubation of bacteria with viruses and virus-free treatments together with nutrient manipulation, and both the sources of mortality in parallel to simultaneously examine the effect of both top-down and bottom-up control on bacterial community.

In this study we extend the line of investigation to a natural freshwater system (Lake Pavin, France) to investigate the variable effect and impact of bottom-up (substrate) and topdown (viruses and heterotrophic nanoflagellates) on the bacterial community. Lake Pavin is a high altitude, meromictic freshwater lake where its late season (autumn) is characterized by lowest annual concentration of nutrient (carbon and inorganic) and chlorophyll pigments, both of which are known to have direct influence on bacterial physiology (inferred from the nucleic acid content, high versus low) and henceforth on viral life styles, namely lytic and lysogeny (Palesse et al. 2014). Therefore the strategies adopted by the viruses, whether to kill or not to kill can have variable impacts on certain members of bacterial community (Bouvier et al. 2007; Pradeep Ram and Sime-Ngando 2008; Chen et al. 2019). Several bacterial groups are known to have specific preferences for nutrient uptake especially during the nutrient depleted season, henceforth it can be expected that different members of the group with varying physiology and activity which tend to occupy different niches could signal changes in host-virus interactions (Øvreås et al. 2003; Liu et al. 2015).

Here we hypothesize that the relative abundances of low and high nucleic acid content bacterial subpopulation possessing differing physiological state and metabolism can strongly be influenced by the presence or type of mortality factors and nutrient supply, which eventually can evoke significant patterns and variations in bacterial community composition and diversity estimates. We also investigated the extent to which we can link bacterial diversity estimates and community composition to top-down and nutrient availability respectively. In this study, high throughput sequencing of 16S rRNA genes using Illumina MiSeq platform was the method of preference for capturing the effect of top-down and bottom-up forcing's on host taxonomical changes in bacterial community because they not only facilitates a rapid and high resolution of host community but also provides information on bacteria-virus interactions at the community level.

\section{MATERIALS AND METHODS}

\section{Study site, sampling and experimental design}

Lake water samples for the experiment was collected from oligo-mesotrophic Lake Pavin (see Palesse et al. [2008] for detailed characteristics) at euphotic depth (5m) using Van Dorn bottle 
at the deepest central point of the lake $\left(45^{\circ} 29^{\prime} \mathrm{N} ; 2^{\circ} 56^{\prime} \mathrm{E}\right)$ on 16 October 2015 (autumn season). The water samples collected in triplicates (i.e. three replicate hauls) were filled in clean insulated carboys and transported to laboratory well protected from heat and light radiations. Upon arrival, the samples were immediately processed for microcosm set up. Preparation of water samples for the experimental setup is shown in Fig. 1. The experiment involved three fractions, 1). "grazer fraction" (containing bacteria, viruses and heterotrophic nanoflagellates, BVF) via filtration through a succession of nylon fibre sieves (150, 63 and $25 \mu \mathrm{m}$ porosities), 2). "grazer free fraction" (containing bacteria and viruses, BV) via filtration through $1 \mu \mathrm{m}$ pore-size filter (cellulose acetate, Sartorius) and 3). "viral reduced fraction" (containing bacteria with depleted viral abundance, B) obtained from washing and flushing out the viruses in 10 fold concentrated samples (by ultrafiltration,Model DC 10LA, Amicon®) with ultrafiltrate (virus free water) according to Weinbeuer and Suttle (1996). For obtaining bacteria and viruses twice that of in situ abundances (BV2x and B2x), the concentrated samples were diluted accordingly with ultrafiltrate to obtain the desired concentration. Both grazer free (BV) and viral reduced fractions (B), which received organic and inorganic nutrients, individually and in combinations, including organic carbon (glucose, $100 \mu \mathrm{M} \mathrm{C})$, nitrate $\left(\mathrm{NaNO}_{3}, 25 \mu \mathrm{M} \mathrm{N}\right)$ and phosphate $\left(\mathrm{NaH}_{2} \mathrm{PO}_{4}, 5 \mu \mathrm{M} \mathrm{P}\right)$ in three different treatments were designated as BV-C, BV-NP, BV-CNP (containing bacteria and viruses at in situ abundances) and B-C, B-NP, B-CNP (represents viral reduced fraction) respectively. The experimental samples were equally distributed in polycarbonate bottles $(5 \mathrm{~L})$ and incubated in the dark at in situ temperature $\left(14.7 \pm 1^{\circ} \mathrm{C}\right)$. The samples were taken at every 12 hour interval from time zero (T0) to 108 hours (T108) for bacterial and viral abundances, and at 24 hour interval from T0 to T96 for viral lytic infection and community composition. Prior to use, all glass wares, tubings and filtration devices coming in contact with the experimental samples were acid washed $(10 \% \mathrm{HCl})$ and thoroughly rinsed with de-ionized water. The experimental microcosms were set up within 4 hours from the time of sampling.

Our reconstitution approach involving filtration and dilution procedures were successful in obtaining desired concentration of bacterial and viral abundances among different microcosms. Viral reduction treatment was chosen to observe the response and development of bacterial communities under reduced viral top-down pressure. The followed procedure was effective in reducing viral abundance by about two fold when compared to its in situ concentration.

\section{Flow cytometry}


Single-celled bacteria and viruses were counted using flow cytometer (FACS Calibur, Becton Dickinson, Franklin Lake, NJ, USA). The optimized flow cytometry protocol (different sample dilutions, threshold levels, flow rates etc.) that was previously validated for the enumeration of bacteria and viruses from Lake Pavin was adopted (Palesse et al. 2014). Samples ( $2 \mathrm{ml}$ each) were fixed with paraformaldehyde ( $0.5 \%$ final concentration) for 30 minutes in the dark at $4^{\circ} \mathrm{C}$. Following fixation, the samples were diluted in $0.02 \mu \mathrm{m}$ filtered TE buffer (10 mM Tris- $\mathrm{HCl}$ and $1 \mathrm{mM}$ EDTA, $\mathrm{pH}$ 8), and stained with SYBR Green I (10,000 fold dilution of commercial stock, Molecular Probes, Oregon, USA). The mixture was incubated for $5 \mathrm{~min}$ at ambient temperature, heated for $10 \mathrm{~min}$ at $80^{\circ} \mathrm{C}$ in the dark, and cooled for $5 \mathrm{~min}$ at room temperature prior to analysis. The samples were then passed through flow cytometer equipped with an air-cooled laser providing $15 \mathrm{~mW}$ at $488 \mathrm{~nm}$ with the standard filter set-up (Brussaard et al. 2010). Bacteria and viruses were discriminated based on side light scatter versus green fluorescence (530 nm wave- length, fluorescence channel 1 of the instrument) plot. Flow cytometry list modes were analyzed using CellQuest Pro software (BD Biosciences, San Jose, CA, USA; version 4.0). TE buffer blanks were routinely examined to control for contamination of the equipment and reagents.

Flow cytometry allowed the identification and quantification of two major bacterial fractions: low nucleic acid content (LNA cells) and high nucleic acid content (HNA cells) based on the differences in the individual cell fluorescence (related to nucleic acid content) and in the side and forward light scattering signal on the cytogram (Gasol et al. 1999; Bouvier et al. 2007).

\section{Heterotrophic nanoflagellate abundance}

Samples for the measurements of heterotrophic nanoflagellate (HNF) abundance were fixed immediately after sampling with $1 \%$ glutaraldehyde (final concentration). Primulin-stained HNF collected on $0.8-\mu \mathrm{m}$ polycarbonate black filters (25 mm diameter) were counted under UV excitation under a LEICA epifluorescent microscope as described by Caron (1983). A total of 200-400 nanoflagellates from each slide were counted along several transects (SD < 10\%). All solutions were filter-sterilized, and a blank was routinely examined to control for contamination of equipment and reagents.

\section{Viral lytic infection}

Viral lytic infection was inferred from the frequency of visibly infected cells (FVIC) according to Pradeep Ram and Sime-Ngando (2008). Bacterial cells contained in $8 \mathrm{ml}$ of 
glutaraldehyde fixed water samples (final concentration 1\%) were collected on copper electron microscope grids (400-mesh, carbon-coated Formvar film) by ultracentrifugation (Beckman coulter SW 40 Ti Swing-Out-Rotor at $70000 \mathrm{x}$ g for 20 minutes at $4^{\circ} \mathrm{C}$ ). Each grid was stained at room temperature $\left(\mathrm{ca} .20^{\circ} \mathrm{C}\right)$ for $30 \mathrm{~s}$ with Uranyl acetate $(2 \% \mathrm{w} / \mathrm{w}, \mathrm{pH}=4)$, rinsed twice with $0.02 \mu \mathrm{m}$-filtered distilled water, and dried on a filter paper. Grids were examined using a JEOL 1200Ex transmission electron microscope (TEM) operated at 80kV at a magnification of 20,000 to $60,000 x$ to distinguish between bacterial cells with and without intracellular viruses. A bacterium was considered infected when at least five viruses, identified by their shape and size, were clearly visible inside the host cell. At least 400-600 bacterial cells were inspected per grid to determine FVIC. Because mature phages are visible only late in the infection cycle, FVIC counts were converted to the frequency of infected cells (FIC) using the equation FIC = 9.524 FVIC - 3.256 (Weinbauer et al. 2002).

\section{DNA Extraction}

Bacteria from the experimental water samples $(150-200 \mathrm{ml})$ were collected onto $0.2 \mu \mathrm{m}$ white polycarbonate membrane filters (Sartorius, Germany) by applying low vacuum and stored for a week at $-20^{\circ} \mathrm{C}$. The total DNA was then extracted from the filters by using Fast DNA spin kit for soil (MP Biomedicals, Germany), which included two consecutive bead-beating steps, first, for $40 \mathrm{~s}$, followed by a second bead beating $60 \mathrm{~s}$ to disrupt additional, previously unlysed cells. Remaining steps were followed as per manufacturer's protocol. Yield and quality of the extracted DNA samples were checked on $0.8 \%$ agarose gel, and the extracted genomic DNA was quantified, checked for purity at A260/280 nm by NanoDrop spectrophotometer (Thermo Scientific, USA.). The DNA was stored at $-20{ }^{\circ} \mathrm{C}$ until further processing.

\section{S rRNA gene amplification and sequencing}

PCR amplification was carried out to amplify V3-V4 conserved regions of bacterial 16S rRNA gene sequences in triplicate using the 16S rRNA gene specific primers (forward primer 5'-CTTTCCCTACACGACGCTCTTCCGATCTACGGRAGGCAGCAG-3' and reverse 5'GGAGTTCAGACGTGTGCTCTTCCGATCTTACCAGGGTATCTAATCCT-3') (Liu et al. 2007). These primers include the Illumina adapter overhang nucleotide sequences (underlined segment) as well as V3-V4-specific sequences producing an amplicon of $460 \mathrm{bp}$ in length. The PCR library preparation was carried out using KAPA Hi Fi Hot Start Ready-mix PCR Kit (KAPA BIOSYSTEMS ${ }^{\circledR}$ U.S.A.). Briefly, each $25 \mu \mathrm{L}$ of PCR reaction contains $10 \mathrm{ng} / \mu \mathrm{L}$ (1 $\mu \mathrm{L}$ ) of genomic DNA template, $12.5 \mu \mathrm{L} 2 \mathrm{X}$ Mastermix KAPA Hi Fidelity DNA polymerase 
(1 U), $10 \mu \mathrm{M}$ each primer and nuclease free water. PCR reactions were carried out with initial denaturation step at $95{ }^{\circ} \mathrm{C}$ for $3 \mathrm{~min}$ followed by 24 cycles of $98{ }^{\circ} \mathrm{C}$ for $30 \mathrm{~s}, 65^{\circ} \mathrm{C}$ for $30 \mathrm{~s}$, and $72{ }^{\circ} \mathrm{C}$ for $30 \mathrm{~s}$ and ended with an extension step at $72{ }^{\circ} \mathrm{C}$ for $5 \mathrm{~min}$. The PCR products were confirmed by $1.5 \%$ agarose gel electrophoresis. Amplicons from respective samples were pooled together in order to decrease the PCR biasness led by stochastic fluctuations in amplification efficiencies and sequenced (paired-end at a length of 300 nucleotides in each direction) on the Illumina MiSeq platform at the INRA, Toulouse (France). Pooling of PCR amplicons has not been significantly shown to influence Illumina based sequencing data and such procedure has been previously done in samples obtained from freshwater systems (Pascault et al. 2014). Sequence data were received as .fastq files and has been archived in NCBI Sequence Read Archive under the accession number PRJNA479735.

\section{Sequence data analysis}

Sequence processing was performed using mothur software, version 1.39.1 (Schloss et al. 2009). The paired-end MiSeq Illumina reads from the samples were aligned and converted to contigs yielding 2,007,708 reads. Sequence analysis of each combined single fasta file was processed using the mothur MiSeq SOP accessed on the 10 December 2016 (Kozich et al. 2013). Sequences having ambiguous characters, homopolymers longer than 8 bp were removed. High-quality sequences were aligned against the mothur version of SILVA bacterial reference sequences (Pruesse et al. 2007) pre clustered, chimeras and singletons removed and OTUs were defined at 97\% identity. Sequence processing was followed as described in Keshri et al. (2017). Alpha and Beta diversity was calculated on rarified data. Non-metric multidimensional scaling (NMDS) was used to visualize the similarity in bacterial communities between samples. Similarity among bacterial communities among different experimental treatments was also assessed using thetayc distance matrix (Yue and Clayton 2005).

\section{Physico chemical parameters}

Water temperature and dissolved oxygen profiles were determined in situ using an YSI Pro $\mathrm{ODO}^{\mathrm{TM}}$ probe (Yellow Springs, Ohio, USA). Phytoplankton concentration was estimated in situ as $\mu \mathrm{g}$ equivalent Chlorophyll- $a \mathrm{~L}^{-1}$ (Chl) using a submersible fluorescence photometer (Fluoroprobe; BBE-Moldaenke, Kiel, Germany). Total organic carbon and total nitrogen concentrations were determined by high temperature catalytic oxidation method $\left(680^{\circ} \mathrm{C}\right)$ using a TOC analyzer (Shimadzu TOC-V CPN, Japan). 


\section{Statistical analysis}

261

262

The response of bacterial and viral parameters to different nutrient (inorganic and organic) additions was tested by analysis of variance (ANOVA), with a significant response at $\mathrm{p}<$ 0.05. Potential relationships among various measured variables were tested by Pearson's correlation analysis. All statistical analyses were performed using Minitab's software for Windows (Release 17, Minitab). Differences in bacterial community composition among the experimental treatments were assessed using UniFrac weighted distance metric (Lozupone et al. 2006). The randomization/permutation procedure analysis of similarities (ANOSIM) was used to evaluate the significant differences between groups. The ANOSIM statistic R displays the degree of separation between groups and is calculated by the difference of the betweengroup and within-group mean rank similarities. The value of $\mathrm{R}=1$ denotes complete separation whereas $\mathrm{R}=0$ suggests no separation (Clarke and Gorley 2001).

\section{RESULTS}

\section{Initial conditions}

The experiment was carried out during the clear water phase where the water temperature (14 $\left.\pm 0.2^{\circ} \mathrm{C}\right)$, dissolved oxygen $\left(8.2 \pm 0.4 \mathrm{mg}^{-1}\right)$, organic carbon $\left(1.8 \pm 0.3 \mathrm{mg}^{-1}\right)$, total nitrogen $\left(0.2 \pm 0.02 \mathrm{mg} \mathrm{l}^{-1}\right)$ and chlorophyll $a\left(1.7 \pm 0.3 \mathrm{mg} \mathrm{l}^{-1}\right)$ concentrations were typical of the studied season. Phosphate concentration was below the detection limit. At the start of the experiment (T0), the mean viral and bacterial abundance were $1.8 \pm 0.2 \times 10^{7} \mathrm{ml}^{-1}$ and $0.9 \pm 0.1 \times 10^{6}$ cells $\mathrm{ml}^{-1}$ respectively, with virus to bacteria ratio of 20. Low nucleic acid bacterial cells (LNA) were 8 times higher than high nucleic acid bacterial cells (HNA). Actinobacteria (69.1\%), Proteobacteria $(17.3 \%$ ), and Bacteroidetes $(10.5 \%)$ together accounted for $97 \%$ of the total bacterial phyla at start of the experiment. HNF abundance estimated the start of the experiment was $1.7 \pm 0.2 \times 10^{3}$ cells $\mathrm{ml}^{-1}$.

\section{Bacterial and viral abundance}

The results presented here correspond to mean value (triplicates) of different incubation times (T0 to T108). Addition of nutrients (carbon+nitrogen+phosphorous) evoked a strong and significant $\left(\mathrm{F}_{1,26}=29.4, \mathrm{p}<0.0001\right)$ increase in bacterial abundance from T48 and T12 in BVCNP and B-CNP compared to T0 (Fig. 2A\&B). The maxima in bacterial abundance that was observed at T108 $\left(12.6 \pm 0.5 \times 10^{6}\right.$ cells ml $\left.{ }^{-1}\right)$ and $\mathrm{T} 72\left(15.0 \pm 0.8 \times 10^{6}\right.$ cells ml $\left.^{-1}\right)$ in BV- 
$\mathrm{CNP}$ and $\mathrm{B}-\mathrm{CNP}$ respectively was one order of magnitude higher than the abundance at the start of the experiment. In both the cases the increase in bacteria was never accompanied by proportional increase in viral abundances, thereby resulting in significantly lower $\left(\mathrm{F}_{1,24}=27.5\right.$, $\mathrm{p}<0.0001$ ) virus to bacteria ratio (range $=1.1-2.2$ ) compared to microcosms without nutrient additions (range $=11.1-23.1$ ). Except in CNP treatments, viruses followed host abundance in the grazer and grazer free fraction resulting in a significant correlation $(r=0.88, p<0.001)$ between the two. Generally, in the viral reduced microcosms continuous or moderate decline in viral abundance was observed from start to end of the experiment (Fig. 2B) Addition of nutrient limiting substrates and viral reductions contributed to the variability of HNA and LNA populations with incubation time. In the microcosms without nutrient additions (BVF, BV and BV2X), LNA was always found to dominate HNA cells (LNA:HNA = 1.4 to 13.9), whereas in microcosms with carbon supplements the reverse was observed (HNA:LNA $=1.0$ to 15.2 ) (Fig. 3). In all viral reduced microcosms, HNA was the dominant subpopulation (Fig. 3).

\section{Phage infection}

Viral lysis was more evident in the grazer treatment where the highest percentage of viral infection $(30.3 \%)$ coincided with the maxima of HNF abundance at T48 (Supplementary material, Fig. S1). Overall, viral lysis in the grazer and grazer free fraction varied by a factor of 10 and was significantly $\left(\mathrm{F}_{1,18}=30.1, \mathrm{p}<0.0001\right)$ higher compared viral reduced treatments (Fig. 4A\&B). High viral lysis did not bring about significant variability in virus to bacteria ratio suggesting a constant production and loss. The significant increase in host population following nutrient addition in grazer free fraction was never accompanied by increase in lytic infection.

\section{$16 S$ rRNA gene sequencing analysis}

A total of 1,168,347 effective sequences after quality and chimera removal were analyzed further with over 15,000 sequences in each library. Clustering at 97\% similarity resulted in a total of 9,183 OTUs. All of the rarefaction curves reached saturation indicating that sequencing depth was considerable enough to cover the whole bacterial diversity (Supplementary material, Fig. S2).

\section{Bacterial community diversity and composition in different microcosms}


Incubations of the resident bacterial assemblage with the presence of viruses and grazers (BVF), viruses alone (BV) and under viral reduction (B) yielded distinct signatures in bacterial diversity and community composition. The variation in bacterial richness (Chao = 328-383) and diversity (Shannon $=3.58-3.75$ ) was higher in the presence of both the loss factors throughout the experiment. Overall, the bacterial diversity under reduced viral concentrations was significantly lower $(\mathrm{p}<0.001)$ compared to microcosms with in situ viral abundances (Supplementary material, Table S1). Addition of glucose and inorganic nutrients in $\mathrm{BV}$ and $\mathrm{B}$ microcosms promoted shifts in bacterial community dominants as a function of carbon source preference, resulting in lower bacterial diversity.

In microcosms, the distribution and relative abundance of different bacterial groups which was visible at the genus level. Out of 16 different phyla along with unclassified bacterial members with varying abundance, 3 phyla namely Actinobacteria, Proteobacteria and Bacteroidetes, approximately accounted for $99 \%$ of the total sequences with varying abundances. The members of Actinobacteria (represented by genera clade hgcI, CL500-29 marine group, Candidatus Planktophila) which were the dominant group at the start of the experiment decreased linearly with time. Proteobacterial members such as Alphaproteobacteria, Betaproteobacteria, Gammaproteobacteria and Bacteroidetes were highly dynamic and showed variable response with progress in incubation time in different microcosms.

Within the class Betaproteobacteria, Limnohabitans increased 3 to 5 fold in BV-CNP treatment, whereas in the viral reduced fractions a notable increase in the relative abundance of genera Delftia, Duganella and Pelomonas was observed (Fig. 5). Similarly the increase of Caulobacter belonging to class Alphaproteobacteria by 6.7 fold compared to start of the experiment was evident in B-NP microcosms. The strong increase of Gammaproteobacteria by 53 and 70.3 fold in the BV-CNP and B-CNP treatment respectively eventually coincided with high percentage increase of HNA cells. This response of Gammaproteobacteria to carbon addition was represented by members belonging to genera Pseudomonas and Acinetobacter in viral reduced and Pseudomonas only in microcosm containing in situ abundances. Among the class Bacteroidetes, the genera Flavobacterium and Sediminibacterium which showed ten and two-fold increase respectively in the presence of both the loss factors only. Overall the sequences from all the microcosms were classified into 29 classes, 69 orders, 135 families and 281 genera.

Two dimensional non-metric multidimensional scaling accounted for bacterial community differences (stress $\left.=0.08, \mathrm{r}^{2}=0.97\right)($ Fig. 6$)$. The variations towards first axis of 
non-metric multidimensional scaling is mostly contributed by OTU2 (Pseudomonas) OTU43 (env.OPS_17_ge from family Sphingobacteriales), OTU122 (Polaromonas) and OTU100 (Rhodococcus). However, OTU10 (Sediminibacterium), OTU66 (Microbacteriaceae), OTU5 (Pseudomonas) and OTU3 (Pseudomonas) contributed most to the variations of second axis. Based on the distribution of OTUs, ANOSIM and weighted UniFrac analyses indicated significant differences $(\mathrm{p}<0.001)$ in bacterial community composition in grazer, grazer free and viral reduced microcosms (Supplementary material Table S2A\&B). The clustering of samples from microcosms with ambient and reduced viral abundance is clearly visible except in the case of CNP supplemented samples. The dendrogram based on thetayc calculators confirmed the hierarchical clustering of bacterial community composition in samples in two clades of the tree and raw samples branched closely with samples from ambient viral abundances microcosms (Supplementary material Fig. S3).

\section{DISCUSSION}

This study provides evidence on the differential impact of top-down (viruses and grazers) and bottom-up (nutrients) forces on bacterial community structure (diversity and composition) which caused shifts in bacterial subpopulation with differing physiological state and metabolism. Two dimensional non-metric multidimensional scaling accounted for structural differences in bacterial community, whereas ANOSIM and UniFrac analysis highlighted for significant differences in bacterial communities in experimental microcosms.

\section{Nutrient impact on bacterial physiology}

The response of natural bacterial communities to nutrients additions can be linked closely to the state of the ecosystem (Øvreås et al. 2003). During the studied period of the year, multiple nutrient limitation of bacterial community was evident with large proliferation of high nucleic acid content bacterial subpopulation in experimental microcosms supplemented with organic and inorganic nutrients (Fig. 2). However, the inability of bacterial cells to divide but increase in their biovolume in microcosms with addition of carbon source alone is suggestive of strong co-limitation of phosphate source (Carlsson and Caron 2001). Phosphate is known to enhance cell division, whereas their strong limitation could result in the storage of organic carbon in cells without dividing and thus maintain higher carbon metabolism (del Giorgio and Cole 1998). The dominance of LNA at the start of the experiment and subsequent increase of HNA cells following the addition of carbon source 
suggest that these two groups may differentiate according to the prevailing nutrient environment and thus play different ecological roles. The explosive growth of HNA cells with nutrient additions is consistent with the reports that an enrichment of copiotrophic bacterial phylotypes (such as those comprise the HNA subpopulation) coincides with bacterial productivity and biomass maxima (Nelson et al. 2014; Mojica et al. 2019). Therefore, nutrient conditions which are bound to vary at different time periods especially in natural freshwater system could serve as a potential influencing factor in altering the bacterial physiological state with high and low concentrations favoring HNA and LNA cells respectively (Palesse et al. 2014; Liu et al. 2015).

The expression of HNA cells under nutrient relaxation could be a part of growth strategy where certain bacteria such as Vibrio are capable of surviving extended periods of carbon starvation and grow rapidly at high substrate concentrations (Øvreås et al. 2003). Our results support and suggest the fact that HNA cells could be fast growing, diverse and be more adapted to changing environments, using their repertoire of transport and regulation genes (Philippot et al. 2010). Such versatility and fast growing nature of HNA cells which possess more flexible genes allow them to exploit pulses of nutrients (Mojica et al. 2019) and occupy more ecological niches (Schattenhofer et al. 2011). Cytometric signatures have revealed that both HNA and LNA cells may represent physiologically and ecologically distinct bacterial populations that have components which are intrinsic to themselves and this distribution may in fact be linked to more general adaptive processes within the bacteria (Bouvier et al. 2007; Mojica et al. 2019). This bimodal distribution could probably play a key role in the functioning of bacterioplankton communities.

\section{Linking top-down and bottom-up effects to bacterial community dynamics}

Top-down forces and nutrients had variable impact on bacterial community. High viral lysis in the presence of top-down forces in non-amended microcosms containing microbial populations at in situ abundances and low viral impact on bacterial population with nutrient additions brought about changes in bacterial community composition and diversity. The explosive increase of fast-growing opportunistic bacteria (i.e. HNA cells) in nutrient spiked microcosms was never accompanied by the increase in phage abundance and infection, thus differing with the reports from marine systems where the limiting nutrient was found to constrain bacterial growth and consequently phage-mediated host cell lysis (Williamson and Paul 2004). Low viral impact on bacterial communities could likely be due to tradeoff which can exists between bacterial traits of antiviral defense (reduction and masking of receptors or 
viral adsorption) and resource competition, where organic enrichment may lower resource competition and allow bacterial communities to pay the costs involved in increasing antiviral defense (Thingstad et al. 2005). Moreover extracellular proteases produced by rapidly growing bacteria can largely play a role in the hydrolytic destruction or modification of viral capsids thus alleviating viral lytic pressure leading to uncoupling between bacterial and viral production (Motegi and Nagata, 2009). In microbial model systems, the magnitude of tradeoff between host and phages are largely influenced by environmental factors especially resources (nutrients) where its limitation can result in the coexistence of both susceptible and resistant hosts in natural communities (Friman and Buckling 2013; Record et al. 2016). Such a scenario of viral defense trade-offs through the expression of host defense mechanisms such as CRISPR-Cas (Barrangou et al. 2007) and restriction enzymes (Labrie et al. 2010) can have predictable effects on their community structure, properties, dynamics and also on their response to environmental changes (Stearns 1989; Jessup and Bohannan 2008). Host defense strategies which tend to contribute to the shape of trade-off curve in a predator-prey system can be either concave (cheap defense) or convex (costly defense) depending on the presence of ancestral and coevolved predators respectively (Huang et al. 2017). The presence of such dynamical trade-off between host and phage, which vary with the environment can eventually affect their ecological interactions and subsequently drive evolutionary changes (Jessup and Bohannan 2008).

The application of next generation sequencing to sequence 16S rRNA genes facilitated in obtaining greater information on taxonomic resolution of bacterial community and their diversity pattern in microcosms. Bacterial diversity was highest in the presence of both the top-down factors indicating that they had tighter control on bacterial communities (Zhang et al. 2007). Contrastingly, the addition of carbon source resulted in lower bacterial diversity estimates due to the proliferation of certain communities which have the ability to rapidly consume available resources (Sandaa et al. 2009; Topper et al. 2012). It has been previously demonstrated that both nutrient and loss factors tend to operate simultaneously in freshwater systems where the former can evoke strong changes in the physiology and metabolic activity of certain members of bacterial population which can eventually make those susceptible communities selectively vulnerable to the later, thus impacting their diversity (Storesund et al. 2015; Pradeep Ram et al. 2016). The observed differences in bacterial communities in response to top-down and bottom-up factors in different treatments with the progress of experiment was highlighted by ANOSIM and weighted UniFrac analyses which is based on the distribution of OTUs where significant difference between the bacterial groups are 
reflected in the differences in their community composition. This was duly supported by two dimensional non-metric multidimensional scaling based on thetayc dissimilarity scores to account for community differences.

The members of class Gamma-, Beta- and Alphaproteobacteria which evoked contrasting and differential responses to nutrient additions and predators are known to belong to HNA subpopulation (Schattenhofer et al. 2011; Mojica et al. 2019), while lineages from Actinobacteria were selected against in all the treatments. The low detection of Gammaproteobacteria under high viral infection rates in the presence top-down factors could be explained by their potential vulnerability to loss factors, whereas their sharp increase in with nutrient supplements is suggestive of their opportunistic lifestyle and adaptability to grow under high-nutrient concentrations (Øvreås et al. 2003; Pinhassi and Berman 2003), much quicker than the viruses could infect them. It was interesting to note that even within Gammaproteobacteria, different genera such as Pseudomonas and Alteromonas had variable responses to nutrient additions and viral reductions respectively.

Although it is very well known that Betaproteobacteria are more substrate responsive, their significant presence of genus Limnohabitans amid both the top-down factors are justified by their ability to efficiently utilize regenerated nutrients from grazing and viral lysis under nutrient limiting conditions (Simek et al. 2001; Pradeep Ram and Sime-Ngando 2008). The high expression of minor genera Pelomonas, Delftia, and Duganella (Betaproteobacteria) and genus Caulobacter (Alphaproteobacteria) under reduced viral conditions are suggestive of their vulnerability to viral infection wherein the scenario of host characteristics could prevail over density (Bouvier and del Giorgio 2007). The increased representation of Sphingobacteria and Flavobacteria (Bacteroidetes) in the presence of both the top down factors are suggestive of its ability to change their morphology (filamentous and floc formation) to escape grazing and at the same time efficiently use regenerated nutrients (Hornak et al. 2005).

The generalizations from a single microcosm experiment should be done with care, even when the experiment was carried out with a defined set of controls, parallels and factorial design. The initial bacterial community composition that was determined at the start of the experiment in the grazer fraction was also applied to other fractions (grazer free and viral reduced) assuming that the initial differences between treatments may overall be small. However such assumption could perhaps be associated with certain amount of bias in our experimental microcosms. Despite of methodological constraints and pit falls associated with our chosen experimental approach, we were able to demonstrate the variable influence of topdown factors especially viral lysis and nutrients on bacterial diversity and community 
composition. The expression of HNA over LNA subpopulation under nutrient enriched and viral depletion was reflected in the changes in bacterial community composition at the genus level. Our study is in agreement within the conceptual idea of simple model version of 'Killing the Winner (KtW)' theory, which postulates that bacterial community diversity is a feature that is essentially top-down controlled by viruses, while community composition is bottom-up controlled by competition for limiting nutrients (Töpper et al. 2012; Storesund et al. 2015). Such a model where the two separate control mechanisms for composition and diversity could be envisaged in our study and therefore can be extended for freshwater bacterial communities. Therefore accordingly, our findings indicate that the competition for growth limiting nutrients can act as a structuring factor for the host community composition which occupies available niches, while top-down factors control the identity and abundance of bacterial hosts within each niche.

\section{ACKNOWLEDGEMENTS}

JK was supported by a postdoctoral fellowship from the Université Clermont Auvergne (formerly Université Blaise Pascal), Clermont Ferrand (France). We thank J. Colombet and F. Perriere for their technical assistance in flow cytometry and nutrient analysis respectively. We appreciate two anonymous reviewers and editor for their time, effort and valuable contributions towards this manuscript.

\section{CONFLICT OF INTEREST: None}

\section{REFERENCES}

Barrangou R, Fremaux C, Deveau et al. Crispr provides acquired resistance against viruses in prokaryotes. Science 2007;315:1709-12.

Berdjeb L, Ghiglione J-F, Jacquet S. Bottom-up versus top-down control of hypo- and epilimnion free-living bacterial community structures in two neighboring freshwater lakes. Appl Environ Microbiol 2011;77:3591-9.

Bouvier T, del Giorgio PA, Gasol JM. A comparative study of cytometric characteristics of high and low nucleic acid bacterioplankton cells from different aquatic systems. Environ Micorbiol 2007;9:2050-66.

Bouvier T, del Giorgio PA. Key role of selective viral-induced mortality in determining marine bacterial community composition. Environ Microbiol 2007;9:287-97. 
Bouvy M, Bettarel Y, Bouvier C et al. Trophic interactions between viruses, bacteria and nanoflagellates under various nutrient conditions and simulated climate change. Environ Microbiol 2011;13:1842-57.

Brussaard C, Payet JP, Winter C et al. Quantification of aquatic viruses by flow cytometry. In: Wilhelm SW, Weinbauer MG, Suttle C (eds). Manual of Aquatic Viral Ecology: ASLO, Chapter 11, 2010, 102-9.

Carlsson P, Caron DA. Seasonal variation of phosphorous limitation of bacterial growth in a small lake. Limnol Oceanogr 2001;46:108-20.

Caron DA. Techniques for enumeration of heterotrophic and phototrophic nanoplankton using epifluorescent microscopy, and comparison with other procedures. Appl Environ Microbiol 1983;46:491-98.

Chen X, Ma R, Yang Y et al. Viral regulation on bacterial community impacted by lysislysogeny switch: A microcosm experiment in eutrophic coastal waters. Front Microbiol 2019;10:1763.

Clarke KR, Gorley RN. PRIMER v5: User manual/tutorial. PRIMER-E, Plymouth:UK, 2001, 91.

del Giorgio PA, Cole JJ. Bacterial growth efficiency in natural aquatic ecosystems. Annu Rev Ecol Syst 1998;29:503-41.

Friman V-P, Buckling A. Effects of predation on real-time host-parasite coevolutionary dynamics. Ecol Lett 2013;16:39-46.

Gasol JM, Zweifel UL, Peters F et al. Significance of size and nucleic acid content heterogeneity as measured by flow cytometry in natural planktonic bacteria. Appl Environ Microbiol 1999;65:4475-83.

Hornak K, Masin M, Jezbera J et al. Effects of decreased resource availability, protozoan grazing and viral impact on the structure of bacterioplankton assemblage in a canyonshaped reservoir. FEMS Microbiol Ecol 2005;52:315-27.

Huang W, Traulsen A, Werner B et al. Dynamical trade-offs arise from antagonistic coevolution and decrease intraspecific diversity. Nat Commun 2017;8:2059.

Jessup CM, Bohannan BJM. The shape of ecological trade-off varies with environment. Ecol Lett 2008;11:947-59.

Keshri J, Pradeep Ram AS, Colombet J et al. Differential impact of lytic viruses on the taxonomical resolution of freshwater bacterioplankton community structure. Water Res 2017;124:129-38. 
Kozich JJ, Westcott SL, Baxter NT et al. Development of a dual-index sequencing strategy and curation pipeline for analyzing amplicon sequence data on the MiSeq Illumina sequencing platform. Appl Environ Microbiol 2013;79:5112-20.

Labrie SJ, Samson JE, Moineau S. Bacteriophage resistance mechanisms. Nat Rev Microbiol 2010;8:317-27.

Liu H, Yuan X, Xu J et al. Effects of viruses on bacterial functions under contrasting nutritional conditions for four species of bacteria isolated from Hong Kong waters. Sci Rep 2015;5:14217.

Liu L, Yang J, Yu Z et al. The biogeography of abundant and rare bacterioplankton in the lakes and reservoirs of China. ISME J 2015;9:2068-77.

Liu Z, Lozupone C, Hamady M et al. Short pyrosequencing reads suffice for accurate microbial community analysis. Nucleic Acids Res 2007;35:e120.

Lozupone C, Hamady M, Knight R. UniFrac — an online tool for comparing microbial community diversity in a phylogenetic context. BMC Bioinformatics 2006;7:371.

Mojica KDA, Carlson CA, Behrenfeld MJ. Regulation of low and high nucleic acid fluorescent heterotrophic prokaryote subpopulations and links to viral-induced mortality within natural prokaryote-virus communities. Microb Ecol 2019, DOI:10.1007/s00248-019-01393-9.

Motegi C, Nagata T. Addition of monomeric and polymeric organic substrates alleviates viral lytic pressure on bacterial communities in coastal seawaters. Aquat Microb Ecol 2009;57:343-50.

Nelson CE, Carlson CA, Ewart CS et al. Community differentiation and population enrichment of Sargasso Sea bacterioplankton in the euphotic zone of a mesoscale mode-water eddy. Environ Microbiol 2014;16:871-87.

Øvreås L, Bourne D, Sandaa RA et al. Response of bacterial and viral communities to nutrient manipulations in seawater microcosms. Aquat Microb Ecol 2003;31:109-21.

Palesse S, Colombet J, Pradeep Ram AS et al. Linking host prokaryotic physiology to viral lifestyle dynamics in a temperate freshwater lake (Lake Pavin, France). Microb Ecol 2014;68:740-50.

Pascault N, Roux S, Artigas J et al. A high-throughput sequencing ecotoxicology study of freshwater bacterial communities and their responses to tebuconazole. FEMS Microb Ecol 2014;90:563-74.

Philippot L, Andersson SGE, Battin TJ et al. The ecological coherence of high bacterial taxonomic ranks. Nat Rev Microbiol 2010;8:523-9. 
Pinhassi J, Berman T. Differential growth response of colony-forming $\alpha$ - and $\gamma$-proteobacteria in dilution culture and nutrient addition experiments from Lake Kinneret (Israel), the Eastern Mediterranean Sea, and the Gulf of Eilat. Appl Environ Microbiol 2003;69:199-211.

Pradeep Ram AS, Chaibi-Slouma S, Keshri J et al. Functional responses of bacterioplankton diversity and metabolism to experimental bottom-up and top-down forcings. Microb Ecol 2016;72:347-58.

Pradeep Ram AS, Sime-Ngando T. Functional responses of prokaryotes and viruses to grazer effects and nutrient additions in freshwater microcosms. ISME J 2008;2:498-509.

Pruesse E, Quast C, Knittel K et al. SILVA, a comprehensive online resource for quality checked and aligned ribosomal RNA sequence data compatible with ARB. Nucleic Acids Res 2007;35:7188-96.

Record NR, Talmy D, Våge S. Quantifying tradeoffs for marine viruses. Front Microbiol 2016;3:251.

Sandaa R-A, Gomez-Consarnau L, Pinhassi J et al. Viral control of bacterial biodiversityevidence from a nutrient enriched marine mesocosm experiment. Environ Microbiol 2009;11:2585-97.

Schattenhofer M, Wulf J, Kostadinov I et al. Phylogenetic characterization of picoplanktonic populations with high and low nucleic acid content in the North Atlantic Ocean. Syst Appl Microbiol 2011;34:470-5.

Schloss PD, Westcott SL, Ryabin T et al. Introducing mothur: open-source, platformindependent, community-supported software for describing and comparing microbial communities. Appl Environ Microbiol 2009;75:7537-41.

Schwalbach M, Hewson I, Fuhrman J. Viral effects on bacterial community composition in marine plankton microcosms. Aquat Microb Ecol 2004;34:117-27.

Simek K, Pernthaler J, Weinbauer MG et al. Changes in bacterial community composition, dynamics and viral mortality rates associated with enhanced flagellate grazing in a meso-eutrophic reservoir. Appl Environ Microbiol 2001;67:2723-33.

Sime-Ngando T. Environmental bacteriophages: viruses of microbes in aquatic systems. Front Microbiol 2014;5:1-14.

Stearns SC. Trade-offs in life-history evolution. Funct Ecol 1989;3:259-68.

Storesund JE, Erga SR, Ray JL et al. Top-down and bottom-up control on bacterial diversity in a western Norwegian deep-silled fjord. FEMS Microb Ecol 2015;91:7. 
630

631

632

633

634

635

636

637

638

639

640

641

642

643

644

645

646

647

648

649

650

651

652

653

654

Suttle CA. Marine viruses-major players in the global ecosystem. Nat Rev Microbiol 2007;5: 801-12.

Thingstad TF, Øvreås L, Egge JK et al. Use of non-limiting substrates to increase size; a generic strategy to simultaneously optimize uptake and minimize predation in pelagic osmotrophs? Ecol Lett 2005;8:675-82.

Töpper B, Thingstad TF, Sandaa RA. Effects of differences in organic supply on bacterial diversity subject to viral lysis. FEMS Microb Ecol 2012;83:202-13.

Weinbauer MG, Hornak K, Jezbera J et al. Synergistic and antagonistic effects of viral lysis and protistan grazing on bacterial biomass, production and diversity. Environ Microbiol 2007;9:777-88.

Weinbauer MG, Suttle CA. Potential significance of lysogeny to bacteriophage production and bacterial mortality in coastal waters of the Gulf of Mexico. Appl Environ Microbiol 1996;62:4374-80.

Weinbauer MG, Winter C, Höfle MG. Reconsidering transmission electron microscopy based estimates of viral infection of bacterioplankton using conversion factors derived from natural communities. Aquat Microb Ecol 2002;27:103-10.

Weitz JS, Wilhelm SW. Ocean viruses and their effects on microbial communities and biogeochemical cycles. F1000 Biol Rep 2012;4:17.

Williamson SJ, Paul JH. Nutrient stimulation of lytic phage production in bacterial populations of the Gulf of Mexico. Aquat Microb Ecol 2004;36:9-17.

Yue JC, Clayton MK. A similarity measure based on species proportions. Commun StatTheor M 2005;34:2123-31.

Zhang R, Weinbauer MG, Qian PY. Viruses and flagellate sustain apparent richness and reduce biomass accumulation of bacterioplankton in coastal marine waters. Environ Microbiol 2007;9:3008-18. 